\title{
Prisoner reentry as myth and ceremony
}

\author{
Loïc Wacquant
}

Published online: 23 December 2010

(C) The Author(s) 2010. This article is published with open access at Springerlink.com

\begin{abstract}
The carceral boom in post-Civil Rights America results not from profitseeking but from state-crafting. Accordingly, we must slay the chimera of the "Prison Industrial Complex" and forsake its derived tale of the "Prisoner Reentry Industry." This murky economic metaphor is doubly misleading: first, most released convicts experience not reentry but ongoing circulation between the prison and their dispossessed neighborhoods; second, the institutions entrusted with supervising them are not market operators but elements of the bureaucratic field as characterized by Pierre Bourdieu. Post-custodial supervision is a ceremonial component of "prisonfare," which complements "workfare" through organizational isomorphism, and partakes of the neoliberal reengineering of the state. Reentry outfits are not an antidote to but an extension of punitive containment as government technique for managing problem categories and territories in the dualizing city. To capture the glaring economic irrationality and bureaucratic absurdities of the oversight of felons behind as well as beyond bars, our theoretical inspiration should come not from the radical critique of capitalism but from the neo-Durkheimian sociology of organization and the neo-Weberian theory of the state as a classifying and stratifying agency.
\end{abstract}

Keywords Prisoner reentry · Prison industrial complex myth · Hyperincarceration · Workfare · Bureaucracy · Ceremony · Penal state

\footnotetext{
This article was written in response to the Forum on "No Exit? The Prison Reentry Industry." I am grateful for the diligent research assistance of Aaron Benavidez, the sharp analytic comments of Megan Comfort and Reuben Miller, and the patience of the editors of Dialectical Anthropology.
}

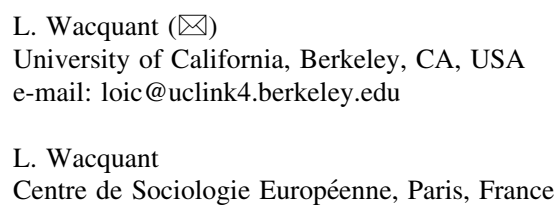


The varied papers gathered by Douglas Thompkins and his collaborators in the special Forum of Dialectical Anthropology on prison reentry offer a kaleidoscopic set of views "from below" of the post-custodial trajectories of American convicts that usefully complement the reigning views "from above" of mainstream criminology, technical penology, and policy-oriented evaluations (e.g., Seiter and Kadela 2003; Petersilia 2003; Travis 2005; Hattery and Smith 2010). But their potential contribution to the much needed rethinking of this urgent sociopolitical issue and its anthropological ramifications is amputated by three serious conceptual flaws. The first is the impulsive embrace of the demonic myth of the "Prison Industrial Complex" (hereafter PIC), which confuses the reengineering of the state in its dealings with the poor in the post-industrial era with a profit-seeking endeavor. The second is the correlative and inconsiderate invocation of a "Prison Reentry Industry" (hereafter PRI), when the management of felons after their release pertains to bureaucratic ceremony rather than economy. The third is the crippling isolation of penal trajectories from the gamut of state policies that jointly determine the life options of convicts both before and after confinement, and especially from the regressive transformation of welfare policies (embracing income support, housing, education, job training, health, etc.) that has accompanied, amplified, and complemented criminal justice changes over the past three decades. I briefly take up each of these points in seriatim before urging a reorientation of critical approaches to penal policy stressing the perverse circularity, economic absurdity, and political rationale of penalization as a technique for governing urban marginality, as well as the need to integrate "workfare" and "prisonfare" into a single framework for analysis and action.

\section{Slay the chimera of the "Prison Industrial Complex"}

The editors of the forum and many of the contributors who have come out of the penitentiary frame their (post)custodial experiences and critiques by reference to the "Prison Industrial Complex," an expression that came into vogue among America's criminal justice activists and progressive scholars and journalists after the mid1990s (Donziger 1996; Davis 1998; Schlosser 1998). The term is, as is too often the case, left undefined and unexplicated, as if its emotional charge and political motive provided sufficient warrant to invoke it. Problem is, to the degree that it can be specified, this wooly notion turns out to be internally incoherent and externally disconnected from the structure and dynamics of carceral expansion in the postCivil rights era. Briefly put, four defects suggest that the chimera of PIC must be slayed, ${ }^{1}$ and the empirical trends and social dilemmas posed by the peregrination of convicts after prison recast as pertaining to the revamping of the state in both its social and penal components (Wacquant 2009).

\footnotetext{
${ }^{1}$ A chimera is a fire-breathing beast in ancient Greek mythology (first described in Homer's Odyssey), sporting the hind of a snake, the body of a goat, and the head of a lion. It is an apt image for the fearsome triadic combination of astringent justice officials, tough-on-crime politicians and media, and booming private corporations which advocates of PIC imagine propel prison trends.
} 
1.1. PIC is based on a loose analogy with MIC, the "Military Industrial Complex" alleged to have driven the expansion of America's warfare economy during the Cold War era (e.g., Gilmore 2009). Aside from the dubious analytic validity of a notion coined by a speechwriter for a despondent President Eisenhower on the occasion of his farewell address, ${ }^{2}$ the claim that PIC parallels MIC in handling security on the home front for the benefit of corporations founders on the fact that there is no justice equivalent for the Pentagon. Whereas the federal Department of Defense is a single decision-making center that manages a single budget and implements military policy through hierarchical command, there exists no bureaucratic lever to direct crime control and submit it uniformly to private interests. Legal punishment in America is meted out through a highly decentralized, disjointed, and multilayered patchwork of agencies. The police, courts, and corrections are separate government institutions, subjected to disparate political, funding, and bureaucratic imperatives, that are poorly coordinated and whose relations are riven with tension and conflicts (Neubauer 2005: 6-7)—to say nothing of probation, parole, halfway houses, drug treatment facilities, and assorted outfits entrusted with handling convicts after their release.

In addition to being weakly connected to each other, each of the three components of the penal chain is deeply fragmented across geographic space and political scale. Over 18,000 local and state law-enforcement agencies decide their policing strategies at ground level; some 2,341 distinct prosecutors' offices set their judicial priorities; thousands of counties run their own jail while the fifty states and the federal government each run their separate prison system (and release programs) with little regard for what other administrative units are doing. Moreover, because they are located at the back-end of the penal chain, prisons depend for their key operational inputs on measures and processes set in motion by the police and the courts, over whom they have virtually no influence. The incipient "federalization of crime" (Waisman 1994), which provides a measure of coordination, has been largely undermined by the diversification of prosecution and corrections philosophies across jurisdictions after the abandonment of indeterminate sentencing (Tonry 2000). In organizational and political terms, then, the government function of punishment is decentralized, fragmented, and horizontal, that is, the polar opposite of the military. The connection between MIC and PIC is purely rhetorical; it pertains to metaphor and not to analogy. Even if some malevolent alliance of politicians, corporate owners, and correctional officials wished to harness carceral institutions to the pecuniary aims of "multinational globalization" and foster "a project in racialization and macro injustice" (Brewer and Heitzeg 2008: 625), they would lack the bureaucratic means to do so. Rather than explaining it, PIC precludes posing the crucial question of how and why a de facto national policy of penal expansion has emerged out of the organizational hodge-podge formed by criminal justice institutions.

\footnotetext{
${ }^{2}$ See Moskos (1974) for an early critique pointing to the multiple flaws and limitations of the notion of "Military Industrial Complex."
} 
1.2. Advocates of PIC maintain that, due to its stupendous enlargement, incarceration plays a major role in the contemporary capitalist economy of the United States, spurring the accumulation process by offering choice opportunities for profit, an endlessly renewed pool of superexploitable labor, and even the valorization of "surplus land" in rural areas (Gilmore 2007). Nationally prisons are said to "constitute an ever growing source of capitalist growth" (Davis 2003: 96) while internationally "the rise of industrialized punishment has woven mass incarceration into the fabric of the global economy" (Sudbury 2004: 13). This claim borders on the absurd. While it is true that the corrections budget of the United States has increased to outlandish proportions by historical and international standards, it still makes up a tiny and negligible chunk of the domestic economy. The $\$ 70$ billion the United States spent in 2008 to operate its jails and prisons (adding up the budgets of counties, states, and the federal government) amounts to less than one-half of one per cent of its Gross Domestic Product of $\$ 14.4$ trillion.

To realize the exaggeration entailed in asserting that prisons have become central to American capitalism (to say nothing of world capitalism), consider that the country's annual expenditures on penal confinement come to about twice the sums Americans disburse for "chocolate, gum, cereal bars and sugar confectionery" (which together generated revenues of $\$ 32.9$ billion in 2008). They equal the size of the personal products industry which includes "over the counter healthcare, skincare, haircare, makeup, fragrances and others" (with sales of $\$ 73.6$ billion); and they come to just over one-half of the monies Americans devote annually to soft drinks (with $\$ 128$ billion). ${ }^{3}$ How credible is the notion that the "Soda Industrial Complex" has become a locomotive for the American economy? Prisons have grown as a government function and a political institution, as a vehicle for regulating marginality and staging the authority of the Leviathan, but they remain negligible in terms of economic weight and thus nonexistent as a vehicle for profit on a national scale-and a fortiori on the global stage.

1.3. A related staple of PIC is the strident denunciation of the exploitation of convict labor. The magazine article by Mike Davis that introduced the term "prison industrial complex" to readers of The Nation in 1995 (in quotation marks and without any explication) was appositely entitled "Hell Factories in the Field." 4 Nearly every piece published since by advocates of the PIC perspective complains in florid language that prisons are being turned into "sweatshops" and inmates reduced to "neo-slavery," as they are pushed into the clutches of capitalist firms eager to recruit pliant low-wage workers behind bars who require

\footnotetext{
3 The economic data in this section are taken from the corresponding "Industry Profile" in Datamonitor, Business Source Complete, EBSCOhost (retrieved 9 October 2010).

4 This title is curious since Davis does not describe carceral production units, noting instead "the drastic shortage of work for prisoners, condemning nearly half the inmate population to serve their sentences idly in their cells watching infinities of television" (Davis 1995: 230). The same Mike Davis compares California prisons to "slave plantations" in his front-cover endorsement of Ruth Gilmore's book Golden Gulag, even though Gilmore concedes in the book that "most prisoners are idle" and that "those who work do so for a public agency" (Gilmore 2007: 21).
} 
no medical coverage, no benefits, no vacation pay, and no pension-as if such employment terms were difficult to impose on the contingent workforce outside. The list of companies said to use prison and jail employees is then rolled out: Wal-Mart, Dell, TWA, Toys "R" Us, Chevron, IBM, Boeing, Nitendo, Starbucks, Victoria's Secret, and so on. The fact that it comprises a Who's Who of corporate America from across economic sectors is presented as definitive proof that inmates have been turned into a coerced reserve army of labor. But the tireless repetition of this list hides the fact that none of these companies ever made more than an incidental or accidental use of prison labor (typically a few hundred staff, hired for short stints through contractors); that none of the industries they lead relies even marginally on convict workers; and that the overwhelming majority of inmates suffer not from labor enslavement but from numbing idleness (Wacquant 2009: 181-184).

Indeed, at peak use around 2002, fewer than 5,000 inmates were employed by private firms, amounting to one-quarter of one per cent of the carceral population. As for the roughly $8 \%$ of convicts who toil for state and federal industries under lock, they are "employed" at a loss to correctional authorities in spite of massive subsidies, guaranteed sales to a captive market of public administrations, and exceedingly low wages (averaging well under a dollar an hour). ${ }^{5}$ Put simply, the notion that convicts constitute a vulnerable labor pool is a figment of the political imagination: it is the dream of advocates of the far Right, who wish to turn penitentiaries into "factories behind bars" to fight idleness and lower the carceral bill, and the nightmare of critics of the far Left who fear that carceral factories are already humming. In reality, for a plethora of stubborn economic, legal, and cultural reasons, prison employment on a mass scale has vanished and is a nonstarter in the liberal societies of the advanced West, including the United States (Van Zyl Smit and Dunkel 1999). ${ }^{6}$

1.4. PIC maintains that the profit-motive drives and distorts punishment, on grounds that firms have inserted themselves into an "industrialized" penal process as suppliers of correctional wares and services, designers and builders of prisons, and even managers of for-profit facilities. But there is nothing new or peculiar in this: the intercession of commercial operators is the norm in the provision of public goods in America. Owing to its weak bureaucratic capacities, there is virtually no

\footnotetext{
5 Compare these figures (under 5,000 employed by firms and an estimated 90,000 by government entities, fewer than half of them black, and all working voluntarily) to this statement, typical of the hyperbole of PIC advocates: "Close to a million young Black men suffer the exploitative regime of the modern prisonindustrial complex, where their virtually unpaid labor is coerced and extracted for corporate profits... This is a situation that resurrects the biophysics of spatio-temporal reduction imposed by slavery and segregation" (Juan 2005: 70).

${ }^{6}$ Britain's new conservative government will soon (re)discover this as it tries to implement its surreal plan to put English and Welsh inmates to work 40 hours a week (to gain job skills and pay for victim reparations and support). Already, the country's Prison Governors' Association has warned that custodial facilities are not equipped for production; that many inmates are not motivated to do drab work and suffer from serious substance abuse and mental impairments; and that employment will require added supervisory staff, whereas the correctional budget and staff are set to decrease by one-third. Not to mention that providing carceral jobs for convicts will hardly please the 2.4 million Britons who are presently unemployed on the outside (nearly one million of them for over a year).
} 
major function of government-education, welfare, health care, housing, transportation, infrastructure, etc. - that does not entail extensive recourse to private entities. In his path-breaking book The Divided Welfare State, Jacob Hacker (2002: 6) has shown that American social policy is distinctive among advanced countries, not for its levels of protection and spending (as commonly believed) but for its longstanding reliance on the private sector to deliver protection against life risks through a "hybrid system of social benefits." For instance, two-thirds of Americans get medical coverage through employer-based health plans offered by insurance companies that are closely regulated and heavily subsidized by government through tax concessions. So much so that private expenditures accounted for $55 \%$ of total health care spending in the country circa 2000. The same is true of aid to the poor: long before the "end of welfare as we know it" in 1996, the lion's share of benefits was delivered through nonprofit and commercial outfits (to the tune of $60 \%$ of expenditures in 1980). The "marketization of welfare" has intensified over the past two decades with the broad expansion of outsourcing for the supervision of workfare recipients, the spread of vouchers, and "the blurring of the distinction between nonprofit and for-profit providers" (Katz 2001: 148-155). Even postsecondary education fits this pattern: $36 \%$ of the $\$ 375$ billion paid out to degreegranting tertiary institutions in 2006-2007 went to private schools (Institute of Education Science 2009: Table 9).

Ironically, the one signal exception to this "mixed economy" of government services is incarceration. In direct contradiction to PIC, what distinguishes punishment in America-as in other advanced societies-is the degree to which it has remained stubbornly and distinctively public. After two decades of gusting ideological winds at their back, favorable economic and budgetary circumstances, frantic lobbying, and the pressing need to expand custodial capacity given grotesque overcrowding in existing facilities, private prison firms managed to capture only $6 \%$ of the "carceral market" at their peak in 2000 (one-fourth of their projected goal of 1995). The bursting of the stock market bubble of 2001 nearly destroyed the sectorits leaders owed their survival to magnanimous new contracts to house immigrant convicts under supervision of the INS - and their share is unlikely to grow much further. As for the overseas market, it is equally limited and stagnant; private corrections get a lot of headlines around the world, but it remains a remarkably marginal "industry" composed of a few small firms whose viability is a brittle by-product of the shifting ideological favors and bureaucratic ineptitude of states. ${ }^{7}$

Incarceration is far and away the one canonical government function that remains firmly in the grip of public officials because penal confinement does not just serve to curb disorder, discipline the unruly, and warehouse the supernumerary. It also

\footnotetext{
7 In 2009, Corrections Corporation of America (CCA), by far the largest of only four international firms of incarceration with half of the planet's private prison "beds," sported a profit of \$155 million on global sales of $\$ 1.7$ billion. By comparison, the world's top corporations tallied profits of $\$ 10$ to $\$ 20$ billion on sales ranging from $\$ 200$ to $\$ 400$ billion. CCA controls assets of $\$ 3$ billion and employs 17,000; leading multinational companies own assets in the hundreds of billions of dollars (excluding financial conglomerates, whose assets range from $\$ 1$ to $\$ 2$ trillion) and employ hundreds of thousands (e.g., Wal-Mart has 1.8 million employees for sales of $\$ 408$ billion generating a profit of $\$ 14$ billion; General Electric employs 307,000 for sales of $\$ 156$ billion and a profit of $\$ 11$ billion). It is hard to see how CCA, being one-hundredth the size of GE, could be playing more than a decorative role in the global economy.
} 
anchors a core civic theater for dramatizing collective norms, asserting political authority, and staging the sovereignty of the state. The prison is a core political institution and not an economic one. ${ }^{8}$ PIC obscures the political logic of penal expansion because it inverts cause and consequence: the ring of "prison profiteers" (Herivel and Wright 2007) has enlarged because the penal state has expanded to gargantuan proportions, and not the other way around.

\section{Prisoner "reentry" pertains to bureaucratic ceremony and not industrial economy}

The penitentiary has returned to the institutional forefront of the advanced societies, not because of its "comprehensive corporatization"-Angela Davis (Davis and Shaylor 2001: 4)—but because the government has shifted from the social welfare to the punitive management of urban marginality through the simultaneous rolling out of disciplinary workfare and neutralizing prisonfare. The penal boom results not from profit-seeking but from state-crafting. Accordingly, it is doubly misleading to invoke murky economic metaphors to speak of a "Prisoner Reentry Industry," as the Forum in Dialectical Anthropology does.

2.1. It is misleading to speak of a reentry industry insofar as the vast majority of former convicts experience not reentry but ongoing circulation between the two poles of a continuum of forced confinement formed by the prison and the dilapidated districts of the dualizing metropolis (Wacquant 2010a) that are the latter's primary recruiting grounds, as the state deploys the criminal justice apparatus to contain the disorders spawned by economic deregulation and welfare retrenchment in the lower regions of social and physical space. Proof is that seven in ten convicts coming out of the gates of American prisons are rearrested and over half of them are thrown back behind bars within 3 years (Langan and Levin 2002). ${ }^{9}$ For them, "reentry" into society would be more accurately described as prelude to another entry into the prison. Similarly, the conventional language of "transition from prison to community" used by practitioners and analysts of "reentry" (e.g., Thompson 2008 for a standard approach) presupposes a clear separation between these two worlds, whereas they increasingly interpenetrate one another under the current regime of hyperincarceration targeted at neighborhoods of relegation-not to mention that these urban wastelands present few of the positive social and moral features commonly associated with the term "community." For lower-class black convicts, who supply the largest contingent of admissions, the bloated prison and the barren hyperghetto stand in a linked relationship of structural continuity, functional

\footnotetext{
${ }^{8}$ See Wacquant (2009: 287-295, 304-30) for further elaboration. McBride (2007) offers an elegant statement of a germane position from the standpoint of political theory. Harcourt (2011) sketches a provocative historical genealogy of the antinomic opposition between the market economy and the penal state.

9 These figures date from the mid-1990s, concerning convicts released in 1994. Everything suggests that the recapture rate has increased since, given that the overall supply of criminals has decreased steadily since. In California, fully three-fourths of the cohorts entering prison around 2000 were composed of "PVRCs" (parole violators returned to custody).
} 
surrogacy, and cultural syncretism such that, irrespective of their custodial status, they remain hemmed in social spaces characterized by extreme material denudment, rampant social suspicion, routine violence, and failing public institutions (Wacquant 2001, 2008: 119-132).

To speak of "pathways of reintegration" (Visher and Travis 2003: 9) disregards the hard fact that there was no integration prior to incarceration as evidenced by the social profile of jail detainees in America (Wacquant 2009: 69-72): fewer than half of them held a full-time job at the time of their arraignment; two-thirds come from households living under half of the official "poverty line"; $87 \%$ have no postsecondary education; and four in ten suffer from serious physical and mental disabilities. Every other jail inmate has an incarcerated family member, and six in ten were previously incarcerated themselves. How could former prisoners be " $r$-integrated" when they were never integrated in the first place and when there exists no viable social structure to accommodate them outside? How could there be "reentry" when they are enmeshed in a carceral lattice spanning the prison and neighborhoods deeply penetrated and constantly destabilized by the penal state?

2.2. It is misleading to speak of a reentry industry because the gamut of institutions entrusted with supervising and supporting convicts after their release are not economic institutions. The industrial metaphor applied to the processing of criminals was given its letters of intellectual nobility two decades ago by the widely read book by criminologist Nils Christie, Crime Control as Industry (1993, second enlarged edition 1994, third edition 2000, reprinted twice since). Writing from the vantage point of his native Norway, a country with an inmate population under 2,300 at the time, where convicted criminals routinely bide their time on a wait-list for months for a cell to become available in the country's miniscule carceral system, and where rehabilitation is a state religion, Christie could not but be shocked by the mammoth size of America's custodial population (then exceeding 1.5 million), its growing reliance on private suppliers and operators, and its abandonment of correctional treatment for brute neutralization and shrill retribution. The only way to make sense of the sheer scale and penological absurdity of American hyperincarceration was to argue that the "segments of the population" that are "seen as superfluous," due to their "inability to participate in the consumer society," are "given a use function as raw materials for the control industry" (Christie 2004: 250). But the "control industry," like the reentry industry, is not an industry in any meaningful sense of the term. As with PIC, this economic language obscures that criminal justice outfits are first and foremost public or parapublic organizations entrusted with delivering sanctions, that is, components of the penal sector of the bureaucratic field as characterized by Pierre Bourdieu (1994).

The gamut of organizations that supervise former prisoners after their release and either assist them in or hinder them from merging into a household, finding housing and employment, and resolving their medical and other personal troubles (described in detail by Ross and Richards 2009) do not form an economic sector. They do not produce or sell goods in an exchange system where price acts as a clearing mechanism; they do not compete with each other for inputs and vie for segments of a market; and they do not generate profits that would provide an impetus for 
further expansion. ${ }^{10}$ They are "people-processing institutions" entrusted with the management of a tainted population of sub-citizens (owing to the judicial stigma afflicting them), which seek to achieve changes in their clients "not by altering basic personal attributes, but by conferring on them a public status and relocating them in a new set of social circumstances" (Hasenfeld 1972: 256). Now, it is true that reentry outfits contend with one another for contracts with local authorities and cash from philanthropic foundations; that they claim to change the attributes of recipients through moral rearmament, soft skills training, and life-coaching techniques; and that they experience the daily scramble over bodies as a form of competition with other human services organizations. But for all the talk of "marketizing" poor oversight in the post-welfare era, reentry operators remain suppliers of services in a public monopsony, with the government (and associated charities) as sole buyer. Their continued functioning hinges not on market efficiency, but on bureaucratic clientelism and political patronage. The conceptual vocabulary needed to describe, explain, and eventually transform the institutions handling reentry is not that of the radical critique of capitalism - and even less so of the loosely associated "isms" of racism, sexism, and militarism, ritually invoked by the advocates of PIC-but the tools of the neo-Durkheimian sociology of bureaucratic organization and the neoWeberian theory of the state. ${ }^{11}$

In their classic essay on "Formal Structure as Myth and Ceremony," John Meyer and Brian Rowan (1977: 346) propose that organizations can be arrayed along a continuum with, at one end, "production organizations under strong output controls" and, at the other, "organizations whose success depends on the confidence and stability achieved by isomorphism with institutional rules." Outfits for postcustodial supervision clearly belong to the latter type, for which "activity has ritual significance: it maintains appearances and validates an organization" (Meyer and Rowan 1977: 354, 355). Such establishments, Meyer and Rowan (1977: 358) point out, are deeply inefficient, but they survive and even thrive by "decoupling" structure and activities, and by following "a logic of confidence and good faith" whereby "delegation, professionalization, goal ambiguity, and the elimination of output data" are enrolled to maintain a "ceremonial façade" (Meyer and Rowan 1977: 358). In short, institutions of penal supervision after incarceration serve less to "reintegrate" convicts who "reenter" society than to cloak the glaring irrationality of the policy of penalization of poverty as the nefarious consequences of hyperincarceration accumulate and fester at the bottom of social and physical space. Denounced upstream and expunged from the prison itself, the welfarist myth of rehabilitation is revived and reactivated downstream after custody to help stage

\footnotetext{
${ }^{10}$ Like other compendia on key economic terms, The Oxford Dictionary of Economics defines an industry as "a sector of the economy, in which firms use similar factor inputs to make a group of related products," followed by a second, older, specification: "A group of sectors, mainly in manufacturing and construction, typically producing physical goods rather than services."

11 The only industry that has grown about "reentry" is the tiny subsector of the publishing world devoted to the genre of practical "handbooks" and advice manuals aimed at (ex-) convicts and their family and friends, and the correctional and social work professionals who oversee them after release. See, from the fast-expanding list of titles typically filled with a mix of sensible pointers, painful anecdotes, and dire warnings, as well as lyrical invocations of the moral individualism that undergirds the national commonsense of Americans, Jackson (2008), Bovan (2009), and Booth (2009).
} 
the resolve of the state to tackle the crime question on an individual, case-by-case basis. Only now this myth is deployed in a stripped-down, panoptic, and disciplinary variant high on symbolism and low on substance, guaranteed to have no more than a marginal impact on the endless recycling of millions of convicts.

For all the excitement it has generated among its advocates since its instigation around 2004 by the Urban Institute and the Open Society Institute (backed by Soros monies), the so-called "reentry movement" is but a minor bureaucratic adaptation to the glaring contradictions of the punitive regulation of poverty. Proof is its measly funding: the Second Chance Act of 2008, ballyhooed by the bipartisan political coalition that passed it and the scholars it subsidizes, has an annual budget of $\$ 165$ million equal to less than one-quarter of one percent of the country's correctional budget. Put differently, it provides the princely sum of $\$ 20$ monthly per new convict released, enough to buy them a sandwich each week. If the authorities were serious about "reentry," they would allocate twenty to fifty times that amount at minimum. They would start by reestablishing the previously existing web of programs that build a bridge back to civilian life-furloughs, educational release, work release, and half-way houses-which has atrophied over the past two decades and avoid locating "reentry services" in decrepit facilities located in dangerous and dilapidated inner-city districts rife with crime and vice (Ross and Richards 2009: 13-15, 48). They would restore the prison college programs that had made the United States an international leader in higher education behind bars, until convicts were denied eligibility for Pell Grants in 1994 to feed the vengeful fantasies of the electorate, even as government studies showed that a college degree is the most efficacious and cost-effective antidote to reoffending (Page 2004). They would end the myriad rules that extend penal sanction far beyond prison walls and long after sentences have been served-such as the statutes barring "ex-cons" from access to public housing, welfare support, educational grants, and voting-and curtail the legal disabilities inflicted on their families and intimates (Comfort 2007). They would restrain and reverse the runaway diffusion of "rap sheets" through government web sites and private firms offering background checks to employers and realtors, which fuels criminal discrimination and gravely truncates the life opportunities of ex-offenders years after they have served their sentence and "come clean" (Blumstein and Nakamura 2009). They would expand substance abuse treatment programs both inside and outside prison since the vast majority of convicts suffer from serious alcohol and drug dependency and yet go untreated by the millions. ${ }^{12}$ They would immediately divert low-level offenders who are mentally ill into medical facilities, instead of continuing to subject them to penal abuse and medical neglect in carceral facilities, as consistently recommended by leading public health experts for over two decades (Steadman and Naples 2005). They would stop the costly and self-defeating policy of returning parolees to

\footnotetext{
12 Nationwide, the United States spent $\$ 468$ billion to handle substance abuse and addiction to tobacco, alcohol, and narcotics in 2005. Less than $2 \%$ of that sum went to prevention and treatment (Califano 2009). This imbalance is even more pronounced among addicted convicts both behind and beyond bars: the California Department of Corrections offers 750 beds in detoxification wards to its 85,000 parolees known to be alcohol or drug addicts.
} 
custody for technical violations of the administrative conditions of their release (Grattet et al. 2008). The list goes on and on.

The twofold point being made here is that, besides serving no productive function, the "reentry industry" is not an industry by dint of its bureaucratic (il)logic and artisanal format. This derives from a signal difference between the military and crime control functions of the state, which PIC and the derivative trope of PRI both ignore and obscure: warfare is a capital- and technology-intensive activity for which the Pentagon necessarily depends on private corporations (in the absence of public sector producers of military wares), whereas justice is a people-intensive activity for which government officials routinely rely on a myriad public outfits and their extensions (nonprofit or commercial). Furthermore, these outfits are not geared toward effecting the "reintegration" of convicts for which budgets, personnel, and political will are lacking, but to performing a simulacrum of rehabilitation after custody while such rehabilitation has been jettisoned in custody. In short, prisoner reentry is not an industry but a bureaucratic charade.

\section{Post-custodial supervision is a component of prisonfare, which complements workfare and partakes of the neoliberal reengineering of the state}

Convict reentry programs activated "downstream" are not only tiny in size, incoherent in design, and grotesquely ineffective-so many properties that would make them a failed industry if they were indeed one. They are also undermined at every turn by the broader set of policies that the state deploys "upstream" on the education, housing, health care, welfare, and labor fronts. In all of these domains, over the three decades spanning the dismantling of the FordistKeynesian compact, federal and local actions have converged to aggravate inequality and to entrench racialized deprivation in the city. ${ }^{13}$ At the same time, the authorities have swung from the social and medical treatment to the penal management of poverty, thus directly fueling admission into the ballooning carceral system and sowing such instability in the nether zones of social and physical space as to render the "reintegration" of convicts after their sentence is served an impractical proposition.

3.1. The multisided and multiscalar involvement of the state in the production and regulation of urban marginality implies that, to properly anatomize the structure and functioning of post-custodial oversight, we must effect three analytic moves: (1) forsake a narrow focus on individual "reentry" —which, for most convicts, is just a step toward repeat incarceration-to capture extended life sequences spanning

\footnotetext{
13 Wacquant (2008) provides an empirical demonstration in the case of Chicago and Brady (2009) a rigorous international comparison showing, first, that inequality and poverty in the advanced societies are tightly correlated and, second, how both result from power relations and political coalitions institutionalized in the state, not from the behavioral failings or cultural patterns of the lower class (as alleged by those scatty sociologists who periodically rediscover with wonderment the mysterious magnetism of the "culture of poverty").
} 
trajectories before and after prison, using the lineage as unit of analysis and tracking the peregrinations of its members across multiple spells of penal entailment ${ }^{14}$; (2) link social and penal policy since these two variants of poverty policy have become interwoven and coordinated under the same punitive philosophy of moral behaviorism; (3) heed the symbolic purposes and ceremonial logic of post-prison supervision, as opposed to its imagined economic rationale, and trace its socially disintegrative and criminogenic effects as well as its proclaimed supportive role.

The sudden policy and scholarly infatuation with "reentry" as individualized response to the collective predicament posed by the mass return of convicts to the dispossessed districts of the metropolis must not hide the fact that such programs are an integral component of prisonfare, defined as the rolling out of the police, the courts, and custodial institutions and their extensions to contain the brewing urban disorders that the state itself has spawned or aggravated by retracting the social safety net and deregulating the low-wage labor market (Wacquant 2009a:16-17, 58-69, 98-109, 135-146). Reentry programs are not an antidote to but an extension of punitive containment as government technique for managing problem categories and territories in the dualizing city. They are not a remedy to, but part and parcel of the institutional machinery of hyperincarceration (Cohen 1985), whose reach they stretch beyond bars and over the lifecourse of convicts by keeping them under the stern watch and punctilious injunctions of criminal justice even as they return to their barren neighborhoods. Reentry must therefore be understood as an element in the redrawing of the perimeter, priorities, and modalities of action of the state as a stratifying and classifying agency and not as an "industry" geared to "reintegrating" a marginalized population that was never socially and economically integrated to start with.

3.2. The recent revamping of post-custodial supervision partakes of the neoliberal reengineering of the state whereby restrictive workfare and expansive prisonfare meet and mesh to impose the discipline of fragmented wage work onto the postindustrial poor, neutralize their more disruptive elements, and project the authority of the Leviathan onto the stage of law and order (Wacquant 2010b). Indeed, the renovated reentry chain is for lower-class criminal men, the penal counterpart and complement to punitive workfare as the new face of public aid for derelict women and children-who happen to be their mothers, sisters, wives, and offspring, since the welfare and criminal justice arms of the state fasten onto the same households located at the foot of the socioracial hierarchy according to a gendered division of control. Both offer meager and temporary support on condition that recipients submit to disciplinary monitoring pointing them to the substandard employment slots of the service economy. Both use the same case-based techniques of surveillance, moral stigma, the abridgement of privacy, and graduated sanctions to

\footnotetext{
14 “The dominant model therefore should not be one of people being taken from 'the community' to be incarcerated out of sight and out of mind until they are released and reintegrated back into society. Instead, one sees a continual flow of people moving in and out of correctional facilities, some for short stays and others for long ones, forming various networks that traverse carceral borders and that are subjected to punitive measures in the domestic and communal spheres" (Comfort 2008: 186). This constant churning of the penalized poor in and out of jail and prison exerts a range of disruptive effects on all generations inside a household, and particularly on the children of convicts (Foster and Hagan 2007).
} 
"correct" wayward behavior. ${ }^{15}$ Both produce not material improvement and social incorporation but forced capitulation to extreme precarity and civic liminality as the normal horizon of life for their clientele. Reentry organizations thus prosper on the penal side thanks to their organizational isomorphism with workfare on the social policy side and to their cultural congruence with the moral individualism animating a political culture that has splintered between a libertarian, laissez-faire attitude toward those perched at the top, and a paternalist and punitive disposition toward those trapped at the bottom. By activating the individualist logic of personal responsibility, post-custodial bureaucracies put the onus of failed "reintegration" on former convicts, thereby screening out the accelerating degradation of the condition of the American working class in the "gloves-off economy" which increasingly consigns them to long-term subemployment and laborious poverty (Kalleberg et al. 2000; Shulman 2005; Bernardt et al. 2008). Lastly, the ceremonial deployment of reentry programs effectively decouples the web of economic, social, urban, and justice policies that absolve the prison from the handling of convicts after incarceration, creating the illusion that the state is not deeply implicated in the entry of convicts. In so doing, it helps legitimize post-festum the penalization of poverty and the normalization of social insecurity at the bottom of the class structure. ${ }^{16}$

To sum up, the so-called Prison Industrial Complex is organizationally antithetical, not analogous, to its alleged precursor, the Military Industrial Complex; it composes a negligible part of the contemporary economy, and not one of its central planks; it does not exploit convict labor or generate self-sustaining profits (except by way of sideshow), but constitutes a gross fiscal drain; and, far from being "corporatized," punishment remains a distinctively and mulishly public function of government. Because it consistently mistakes a political exercise in state-building for a capitalist quest for profit (stoked by the evils of racism, sexism and imperialism), PIC supplies no analytic traction on the prison boom in post-Civil rights America and on the punitive revamping of the neoliberal Leviathan on both the social and penal fronts. Worse, it blinds us to the colossal economic irrationality and Kafkaesque bureaucratic absurdity of hyperincarceration. Consequently, we must jettison the hazy economic metaphor of the "Prison Reentry Industry" and grasp the changing scale, organization, and effects of programs of post-custodial supervision as the ceremonial components of a broader refurbishing of the bureaucratic field in its dealing with the disqualified fractions of the post-industrial working class. Our theoretical inspiration should come not from Karl Marx and Frantz Fanon but from Emile Durkheim, Max Weber, and Pierre Bourdieu, insofar as the contemporary prison is at core a political institution - a concentrate of material and symbolic violence-and not an economic outfit or a racial organization. More crucially still, we should reaffirm our empirical commitment to tracking the phenomenon of "reentry" as it actually unfolds at ground level, that is, not as satanic mills of punishment for lucre but as a penal morality play and bureaucratic farce.

\footnotetext{
15 This is amply documented by Sharon Hays's (2003) and Collins and Mayer's (2010) lucid accounts of the workfare policy at ground level. See also the complementary view offered by Watkins-Hayes (2009) portrait of the new-style welfare bureaucrats at work.

${ }^{16}$ Peck and Theodore (2009) show how the "job developers" who funnel ex-convicts toward day-labor agencies effect this work of normalization in "Carceral Chicago."
} 
Open Access This article is distributed under the terms of the Creative Commons Attribution Noncommercial License which permits any noncommercial use, distribution, and reproduction in any medium, provided the original author(s) and source are credited.

\section{References}

Bernhardt, Annette, Heather Boushey, Laura Dresser and Chris, Tilly. 2008. The gloves-off economy: Workplace standards at the bottom of America's labor market. Champaign, IL: Labor and Employment Relations Association.

Blumstein, Alfred, and Kiminori Nakamura. 2009. Redemption in the presence of widespread criminal background checks. Criminology 47(2): 327-359.

Boothe, Demico. 2009. Getting out and staying out: A black man's guide to success after prison. Memphis, TN: Full Surface Publishing.

Bourdieu, Pierre. [1993] 1994. Rethinking the state: On the genesis and structure of the bureaucratic field, Sociological Theory 12(1): 1-19.

Bovan, Richard. 2009. The dedicated ex-prisoner's guide to life and success on the outside: 10 rules for making it in society after doing time. Memphis, TN: Full Surface Publishing.

Brady, David. 2009. Rich democracies, poor people: How politics explain poverty. New York: Oxford University Press.

Brewer, Rose M., and Nancy A. Heitzeg. 2008. The racialization of crime and punishment: Criminal justice, color-blind racism, and the political economy of the prison industrial complex. American Behavioral Scientist 51(5): 625-644.

Califano, Joseph A. 2009. Shoveling up II: The impact of substance abuse on federal, state and local budgets. New York: National Center on Addiction and Substance Abuse at Columbia University.

Christie, Nils. 1993. Crime control as industry: Toward gulags, Western style? London: Routledge.

Christie, Nils. 2004. Imprisonment, sociological aspects. In: International encyclopedia of the social and behavioral sciences, eds. Neil J. Smelser and Paul B. Baltes, 7248-7251. London: Pergamon Press.

Cohen, Stanley. 1985. Visions of social control. Cambridge, UK: Polity Press.

Collins, Jane L., and Victoria Mayer. 2010. Both hands tied: Welfare reform and the race to the bottom in the low-wage labor market. Chicago: University of Chicago Press.

Comfort, Megan. 2007. Punishment beyond the legal offender. Annual Review of Law \& Social Science 3: 271-296.

Comfort, Megan. 2008. Doing time together: Love and family in the shadow of the prison. Chicago: University of Chicago Press.

Davis, Angela. 1998. What is the prison industrial complex? What does it matter. Colorlines: Race, Culture, Action.

Davis, Angela Y. 2003. Are prisons obsolete? New York: Seven Stories Press.

Davis, Angela, and Cassandra Shaylor. 2001. Race, gender, and the prison industrial complex: California and beyond. Meridians 2(1): 1-25.

Davis, Mike. 1995. A prison industrial complex: Hell factories in the field. The Nation, 20: 229-234.

Donziger, Marc R. 1996. The prison industrial complex. In: The Real War on Crime, 63-98. New York: Harper Perennial.

Fairbanks, Robert P. 2009. How it works: Recovering citizens in post welfare Philadelphia. Chicago: University of Chicago Press.

Foster, Holly, and John Hagan. 2007. Incarceration and intergenerational social exclusion. Social Forces 54, no. 4: 399-433.

Gilmore, Ruth. 2007. Golden gulag: Prisons, surplus, crisis, and opposition in globalizing California. Berkeley: University of California Press.

Gilmore, Ruth. 2009. From military industrial complex to prison industrial complex. In: Recording carceral landscapes, ed. Trevor Paglen, 1-11. Berkeley: The Lef Foundation.

Grattet, Ryken, Joan Petersilia, and Jeffrey Lin. 2008. Parole violations and revocations in California. Irvine, CA: Center for Evidence-Based Corrections.

Hacker, Jacob S. 2002. The divided welfare state: The battle over public and private social benefits. New York: Cambridge University Press.

Harcourt, Bernard. 2011. The illusion of free markets: Punishment and the myth of natural order. Cambridge: Harvard University Press. 
Hasenfeld, Yeheskel. 1972. People processing organizations: An exchange approach. American Sociological Review 37(3): 256-263.

Hays, Sharon. 2003. Flat broke with children: Women in the age of welfare reform. New York: Oxford University Press.

Hattery, Angela, and Earl Smith. 2010. Prisoner re-entry and social capital: The long road to reintegration. Lanham, MD: Lexington Books.

Herivel, Tara J., and Paul Wright. 2007. Prison profiteers: Who makes money from mass incarceration. New York: New Press.

Institute of Education Science. 2009. Digest of education statistics, 2009. Washington, DC: National Center for Education Statistics.

Jackson, Michael B. 2008. How to do good after prison: A handbook for successful reentry (w/ Employment information handbook). PlaceTBD: Joint FX Press.

Juan, E. San, Jr. 2005. Preparing for the time of reparation: Speculative cues from W.E.B. Du Bois, George Jackson and Mumia Abu-Jamal. Souls: A Critical Journal of Black Politics, Culture \& Society 7(2): 63-74.

Kalleberg, Arne L., Barbara F. Reskin, and Ken Hudson. 2000. Bad jobs in America: Standard and nonstandard employment relations and job quality in the United States. American Sociological Review 65(2): 256-278.

Katz, Michael B. 2001. The price of citizenship: Redefining the American welfare state. New York: Owl Books.

Langan, Patrick and D.J. Levin. 2002. Recidivism of prisoners released in 1994. Washington, DC: Bureau of Justice Statistics.

McBride, Keally. 2007. Punishment and political order. Ann Arbor: University of Michigan Press.

Meyer, John W., and Brian Rowan. 1977. Institutionalized organizations: Formal organizations as myth and ceremony. American Journal of Sociology 83(2): 340-363.

Moskos, Charles C., Jr. 1974. The concept of the military-industrial complex: Radical critique or liberal bogey? Social Problems 21(4): 498-512.

Neubauer, David W. 2005. America's courts and the criminal justice system. Belmont, CA: Thompson.

Page, Joshua. 2004. Eliminating the enemy: The import of denying prisoners access to higher education in Clinton's America. Punishment \& Society 6(4): 357-378.

Peck, Jamie, and Nik Theodore. 2009. Carceral Chicago: Making the ex-offender employability crisis. International Journal of Urban and Regional Research 32(2): 251-281.

Petersilia, Joan. 2003. When prisoners come home: Parole and prisoner reentry. New York: Oxford University Press.

Ross, Jeffrey Ian, and Stephen C. Richards. 2009. Beyond bars: Rejoining society after prison. New York: Alpha Publishing.

Seiter, RP., and KR. Kadela 2003. Prisoner reentry: What works, what does not, and what is promising. Crime \& Delinquency 49(3): 360-388.

Schlosser, Eric. 1998. The Prison-industrial complex. The Atlantic Monthly 282: 51-77.

Shulman, Beth. 2005. The betrayal of work: How low-wage jobs fail 30 million Americans. New York: New Press.

Steadman, Henry J., and Michelle Naples. 2005. Assessing the effectiveness of jail diversion programs for persons with serious mental illness and co-occurring substance use disorders. Behavioral Sciences \& the Law (Special Issue on diversion from the criminal justice system), 23(2): 163-170.

Sudbury, Julia. 2004. A world without prisons: Resisting militarism, globalized punishment and empire. Social Justice 31(1-2): 9-33.

Thompson, Anthony C. 2008. Releasing prisoners, redeeming communities: Reentry, race, and politics. New York: New York University Press.

Tonry, Michael. 2000. Fragmentation of sentencing and corrections in America. Alternatives to Incarceration 6(2): 9-13.

Travis, Jeremy. 2005. But they all come back: Facing the challenges of prisoner reentry. Washington, DC: Urban Institute Press.

Van Zyl Smit, Dirk and Frieder Dunkel (eds). 1999. Prison labour: Salvation or slavery? International perspectives. Farnham, UK: Ashgate Publishing.

Visher, Christy A., and Jeremy Travis. 2003. Understanding individual pathways: Transitions from prison to community. Annual Review of Sociology 29:89-113.

Wacquant, Loïc. 2001. Deadly symbiosis: When ghetto and prison meet and mesh. Punishment \& Society 3(1): 95-133. 
Wacquant, Loïc. 2008. Urban outcasts: A comparative sociology of advanced marginality. Cambridge, UK: Polity Press.

Wacquant, Loïc. 2009. Punishing the poor: The neoliberal government of social insecurity. Durham and London: Duke University Press.

Wacquant, Loïc. 2010a. Class, race and hyperincarceration in revanchist America. Daedalus (thematic issue on the challenges of mass incarceration) 140(3): 74-90.

Wacquant, Loïc. 2010b. Crafting the neoliberal state: Workfare, prisonfare and social insecurity. Sociological Forum 25(2): 197-220.

Waisman, Viviana (ed.). 1994. Symposium on the federalization of crime. Hastings Law Journal 46(4).

Watkins-Hayes, Celeste. 2009. The new welfare bureaucrats: Entanglements of race, class, and policy reform. Chicago: University Of Chicago Press. 